Adventure Tourism Research: a Guide to the Literature

Ralf Buckley

International Centre for Ecotourism Research,

Griffith University, Gold Coast, Australia 9726.

r.buckley@griffith.edu.au 


\title{
Adventure Tourism Research: a Guide to the Literature
}

\begin{abstract}
Adventure tourism is a substantial industry sector which to date has received relatively little research attention. Most relevant research is from outdoor recreation. The major research themes are: psychological, including thrills, conflicts and norms; safety, including injuries, illnesses and insurance; impacts, whether ecological, social or economic; and participation and management. There has been rather little research on the structure of adventure tourism products or associated business aspects. Future research priorities include: operational audits; commercial statistics; client characteristics; site geography; equipment manufacture; safety and insurance; recreation ecology; adventure destination marketing; and links with amenity migration and lifestyle.
\end{abstract}

\section{Introduction}

Adventure tourism is a large but little-studied sector (Buckley 2004a, Travel Industry Association of America, 2005). Here, therefore, I review the principal themes addressed to date in adventure tourism research, in order to identify future priorities.

This review does not attempt to summarise the findings of each individual piece of published research, but rather to discern the major directions in the research literature overall. To achieve this as succinctly as possible, clusters of related references are presented in tabular form. The number of references listed for different topics in these tables is not itself a measure of research effort, since for some topics there are recent reviews and for others there are not. Rather, the titles and structure of the tables are intended to illustrate the research themes identified, and the references are there to demonstrate the data behind these patterns. 
Adventure tourism has been variously defined (Weaver, 1998; Fennell, 1999; Manning, 1999; Bentley et al., 2000, 2001a,b,c; Buckley, 2000, 2004a; Bentley and Page, 2001; Newsome et al., 2001; Page and Dowling, 2002). Broadly, it means guided commercial tours where the principal attraction is an outdoor activity which relies on features of the natural terrain, generally requires specialised sporting or similar equipment, and is exciting for the tour clients.

There seem to be five books of particular relevance to adventure tourism: Miles and Priest (1999) on adventure programming in outdoor education; Hudson (2002), focussing principally on sports tourism; Swarbrooke et al. (2003) on human adventure psychology; Easson (2006) on the philosophy and psychology of extreme sports; and Buckley (2006) on the structure of adventure tourism products.

The majority of relevant research literature, however, seems to be derived from other fields of tourism, outdoor recreation and outdoor education. Texts on ecotourism, recreational tourism, tourism in protected areas and even wilderness management and say little or nothing about adventure tourism, though some do mention commercial outfitters and outdoor recreational activities briefly.

\section{Research Themes}

The principal themes in adventure recreation research have been psychological, focussing on the reasons why people engage in adventure activities and their experiences whilst doing so (Table 1). Adventure tourists want to be thrilled and perhaps frightened but not actually endangered (Cater, 2005). Such sensation seeking behaviour, and perceptions of risk, have been reviewed more generally by Cheron and Ritchie (1982), Ewert and Hollenhorst (1989), Crawford et al. (1991), Slanger and Rudestam (1997), Jack and Ronan (1998), Holyfield (1999) and Fluker and Turner (2000).

Behavioural norms, and ways to measure and change them, have received particular attention (Table 1). Recent reviews include Manning et al. (2002, 2004) and Manning and Freimund (2004). One useful practical application is through codes of conduct. 
These have proliferated in many sectors worldwide, but their effectiveness has rarely been tested, and generally found wanting. Scarpaci and Dayanthi (2003), for example, found that swim-with-dolphin tour operators persistently breached an operational code of conduct even though it was a legislated condition of their operating permits and there were identified observers on board their vessels.

Conflicts between practitioners of different activities in the same area have also received attention. In addition to the activity-specific examples in Table 2, general reviews have been provided by Jacob and Schreyer (1980), Devall and Harry (1981), Hendricks (1995), Watson (1995), Schneider (2000) and Vaske et al. (2004). Conflicts may be triggered by fashion, age, gender or experience, as well as different activities. They may occur between commercial tour clients and private exponents of the same activity. They are especially common between motorised and non-motorised users of the same areas, where motorised users seem to be unaware or indifferent to their impacts on the silence, solitude and safety of non-motorised users.

Accident and injury statistics provide another major theme (Table 3). Most of the original data are presented in medical journals, but the tourism implications are summarised well by Bentley et al. (2003) and Page et al. (2003, 2005). Snow sports and diving have been investigated most intensively, with reports on the frequencies of different injuries and the effects of age, experience and safety equipment.

The environmental impacts of outdoor recreation have received some attention, and much of this is directly applicable in commercial adventure tourism. Some impacts, activities and areas have been analysed much more than others (Table 4). There are also reviews of impacts on particular ecosystem components, such as Beale and Monaghan (2004), Buckley (2004b,c) and Cole (2004).

From a tourism management perspective, one of the critical issues is whether interpretation, especially by commercial tour guides, can successfully reduce visitor impacts. There seem to be only two relevant studies, by Medio et al. (1997) for divers and Littlefair (2004) for hikers. 
The economic and to a lesser extent the social impacts of some adventure tourism subsectors have also been addressed, but only in some areas (Table 4), and using a variety of different definitions and estimation methods (Buckley, 1998; Mallett, 1998; Page et al., 2005).

Relatively few authors have described the structure of individual adventure tourism products (Table 5). There are, however, a number of descriptions of outdoor recreation activities, commercial as well as individual, at particular adventure destinations; and various analyses of participation rates and preferences (Table 5). Participation in adventure tourism and recreation has also attracted particular attention from a land management perspective (Cordell and Bergstrom, 1991; Watson et al., 1995; Cole, 1996; Hammitt and Cole, 1998; Bowker, 2001; Hendee and Dawson, 2002; Ewert and Jamieson, 2003; Outdoor Industry Association, 2005).

\section{Research priorities}

Any selection of research priorities will probably reflect the disciplinary background of the person making the selection. With that caveat, here are my suggestions: 
- operational audits and case studies of individual adventure tourism products as a basis for general trend and pattern analyses.

- commercial statistics: how many businesses offer what products where and at what price.

- client characteristics: when, where and for how long they travel, and how such patterns depend on demographic factors.

- similarities and differences between adventure tourism and non-commercial adventure recreation, so as to apply recreation research to adventure tourism

- geography of icon and secondary sites for different adventure activities, both extreme and routine.

- manufacture and sale of adventure equipment: technologies, designs, materials, models, prices, volumes, partitioning between manufacturers, changes in product mixes over time, alliances between manufacturers and lobby groups.

- legal wording of waivers, disclaimers, indemnities, insurances and permit conditions.

- accident and disease statistics for different areas and activities recreation ecology: impacts of different activities under different conditions on different ecosystem components

- social impacts of adventure tourism operations on local residents and communities

- links between adventure tourism and amenity migration.

- links between adventure tourism and broader lifestyle aspects.

\section{Conclusions}

Most of the research currently applied in commercial adventure tourism is actually derived from the outdoor recreation literature. Adventure tourism deserves research attention in its own right. In particular, the focus to date seems to have been on the individual participants, their risks and experiences. The business and geography of adventure tourism products, packages and providers seems to have been ignored. 
Table 1. Psychological Aspects of Adventure Tourism

\begin{tabular}{|l|l|l|l|}
\hline Activity & Thrills, Attitude & $\begin{array}{l}\text { Norms, Codes, } \\
\text { Compliance }\end{array}$ & Service, Guiding \\
\hline Raft, kayak & & $\begin{array}{l}\text { Shelby 1981; } \\
\text { Wellman } \text { et al. 1982; } \\
\text { Shelby et al. 1996 }\end{array}$ & $\begin{array}{l}\text { Arnould and Price } \\
\text { 2003; Sharpe 2005 }\end{array}$ \\
\hline Dive, snorkel & & Inglis et al. 1999 & O'Neill et al. 2002 \\
\hline Surfing & Farmer 1992 & & \\
\hline $\begin{array}{l}\text { Climbing, } \\
\text { mountaineering }\end{array}$ & $\begin{array}{l}\text { Ewert 1994; Breivik } \\
\text { 1996; Feher } \text { et al. } \\
\text { 1998; Schuster } \text { et al. } \\
\text { 2001; Delle Fave } \text { et al. } \\
\text { 2003 }\end{array}$ & Jakus and Shaw 1997 & $\begin{array}{l}\text { Parker and Avant } \\
\text { 2000; Beedie 2003 }\end{array}$ \\
\hline Hike & $\begin{array}{l}\text { Manning 1999; } \\
\text { Chhetri } \text { et al. 2004 }\end{array}$ & $\begin{array}{l}\text { Vaske } \text { et al. 1986; } \\
\text { Manning } \text { et al. 2002, } \\
\text { 2004; Vaske and } \\
\text { Donnelly 2002; } \\
\text { Needham } \text { et al. 2004 }\end{array}$ & \\
\hline Snowmobile & $\begin{array}{l}\text { Gyimothy and } \\
\text { Mykletun 2004 }\end{array}$ & $\begin{array}{l}\text { Gjerdalen and } \\
\text { Williams 2000; } \\
\text { Carlson 2001; Scarpaci } \\
\text { and Dayanthi 2003; } \\
\text { Garrod and Fennell } \\
\text { 2004 }\end{array}$ & \\
\hline $\begin{array}{l}\text { Wildlife, } \\
\text { marine and } \\
\text { estuarine }\end{array}$ & & & \\
\hline
\end{tabular}

Table 2. Activity-Based Conflicts in Adventure Tourism

\begin{tabular}{|l|l|l|}
\hline Activity 1 & Activity 2 & References \\
\hline skiers & snowmobilers & $\begin{array}{l}\text { Knopp and Tyger 1973; Jackson and Wong 1982; Vaske } \text { et } \\
\text { al. 2000; Vitterso et al. 2004; }\end{array}$ \\
\hline skiers & snowboarders & $\begin{array}{l}\text { Williams } \text { et al. 1994; Thapa and Graefe 2003; Vaske } \text { et al. } \\
\text { 2004; }\end{array}$ \\
\hline hikers & riders, packers & Watson et al. 1994; Blahna et al. 1995; \\
\hline hikers & mountain bikers & Watson et al. 1991; Ramthun 1995; Carothers et al. 2001; \\
\hline paddlers & motorboaters & Shelby 1980; Adelman et al. 1982; \\
\hline
\end{tabular}


Table 3. Risks, Accidents and Sickness in Adventure Tourism

\begin{tabular}{|c|c|}
\hline Activity & Reference \\
\hline Raft, kayak & Schoen and Stano 2002; Bentley et al. 2003; Page et al. 2003 \\
\hline Dive, snorkel & $\begin{array}{l}\text { Wilks 1992, 1993, 1999; Byrd and Hamilton 1997; Wilks and } \\
\text { Davis 2000; Trevett et al. 2001; Bentley et al. 2003; Page et al. } \\
\text { 2003; Taylor et al. } 2003\end{array}$ \\
\hline Surfing & Nathanson et al. 2002 \\
\hline Ski/snowboard & $\begin{array}{l}\text { Garrick and Kurland 1971; Requa et al. 1997; Johnson et al. 1997; } \\
\text { Deibert et al. 1998; Goulet et al. 1999; Prall et al. 1995; Tarazi et } \\
\text { al. 1999; Machold et al. 2000, 2002; Macnab et al. 2002; Ronning } \\
\text { et al. 2000; Yamakawa et al. 2001; Federiuk et al. 2002; Hagel et } \\
\text { al. 2004; Levy et al. 2002; Matsumoto et al. } 2002\end{array}$ \\
\hline $\begin{array}{l}\text { Climbing, } \\
\text { mountaineering }\end{array}$ & $\begin{array}{l}\text { Bentley et al. 2003; Williamson 1999; Malcolm 2001, Page et al. } \\
2005\end{array}$ \\
\hline Riding, biking & Bentley et al. 2003 \\
\hline
\end{tabular}


Table 4. Ecological and Socioeconomic Impacts of Adventure Tourism

\begin{tabular}{|c|c|c|}
\hline Activity & Ecological impacts & Economic and social impacts \\
\hline Raft, kayak & & $\begin{array}{l}\text { Bowker et al. 1996; } \\
\text { English and Bowker } 1996\end{array}$ \\
\hline Dive, snorkel & $\begin{array}{l}\text { Allison 1996; Hawkins et al. } \\
\text { 1999; Jameson et al. 1999; } \\
\text { Schaeffer et al. 1999; Schleyer } \\
\text { and Tomalin 2000; Rouphael and } \\
\text { Inglis 2001; Tratalos and Austin } \\
\text { 2001; Zakai and Chadwick- } \\
\text { Furman 2002; Musa } 2003\end{array}$ & $\begin{array}{l}\text { Park et al. 2002; Green and } \\
\text { Donnelly } 2003\end{array}$ \\
\hline Ski/Snowboard & $\begin{array}{l}\text { Buckley et al. 2000; Hadley and } \\
\text { Wilson 2004; Watson and Moss } \\
2004\end{array}$ & \\
\hline Riding & $\begin{array}{l}\text { Weaver and Dale 1978; Whinam } \\
\text { et al. 1994; Newsome et al. 2004a }\end{array}$ & \\
\hline $\begin{array}{l}\text { Climb, cave, } \\
\text { mountaineering }\end{array}$ & $\begin{array}{l}\text { Camp and Knight 1998; Farris } \\
1998\end{array}$ & $\begin{array}{l}\text { Hanley et al. 2001, 2003; } \\
\text { Grijalva et al. } 2002\end{array}$ \\
\hline Hiking & $\begin{array}{l}\text { Cole 2004; } \\
\text { Marion and Leung } 2004\end{array}$ & \\
\hline Biking & $\begin{array}{l}\text { Goeft and Alder 2000; Thurston } \\
\text { and Reader } 2001\end{array}$ & Fix and Loomis 1997 \\
\hline Off-road, ATV & $\begin{array}{l}\text { Neumann and Merriam 1972; } \\
\text { Vail and Heldt 2004; Buckley } \\
\text { 2004a }\end{array}$ & \\
\hline $\begin{array}{l}\text { Wildlife, } \\
\text { terrestrial }\end{array}$ & $\begin{array}{l}\text { Beale and Monaghan 2004; } \\
\text { Buckley 2004b }\end{array}$ & $\begin{array}{l}\text { Barnes et al. 1999; Wilkie and } \\
\text { Carpenter 1999a,b; Archabald } \\
\text { and Naughton-Treves 2001; } \\
\text { Mvula 2001; Thompson and } \\
\text { Homewood 2002; Sekhar 2003; } \\
\text { Adams and Infield } 2003\end{array}$ \\
\hline Wildlife, marine & $\begin{array}{l}\text { Kovacs and Innes 1990; Blane } \\
\text { and Jaakson 1994; Corkeron } \\
\text { 1995; Bejder et al. 1999; } \\
\text { Constantine 2000; Scarpaci et al. } \\
\text { 2000; Nowacek et al. 2001, 2004; } \\
\text { Higham and Lusseau 2004 }\end{array}$ & $\begin{array}{l}\text { Duffus and Dearden 1993; Davis } \\
\text { and Tisdell 1996; Hoyt 2000; } \\
\text { Parson et al. } 2003\end{array}$ \\
\hline
\end{tabular}


Table 5. Products, Destinations and Participation in Adventure Tourism

\begin{tabular}{|c|c|c|c|}
\hline Activity & Product structure & $\begin{array}{l}\text { Destination } \\
\text { summaries, } \\
\text { management }\end{array}$ & $\begin{array}{l}\text { Participation rates, } \\
\text { types }\end{array}$ \\
\hline Raft, kayak & & & $\begin{array}{l}\text { Ewert and Jamieson } \\
2003\end{array}$ \\
\hline Dive, snorkel & $\begin{array}{l}\text { Tabata 1992; } \\
\text { Shackley 1998; Livet } \\
1997\end{array}$ & $\begin{array}{l}\text { Tabata 1989; } \\
\text { Hawkins and Roberts } \\
\text { 1994; Davis and } \\
\text { Tisdell } 1996\end{array}$ & $\begin{array}{l}\text { Mundet and Ribera } \\
2001\end{array}$ \\
\hline Ski/snowboard & & $\begin{array}{l}\text { Fredman and } \\
\text { Herberlein } 2003\end{array}$ & \\
\hline Riding (horse, camel) & Shackley 1996a & & \\
\hline $\begin{array}{l}\text { Climbing, } \\
\text { mountaineering }\end{array}$ & $\begin{array}{l}\text { Johnson and Edwards } \\
1994\end{array}$ & $\begin{array}{l}\text { Wyder 1987; Suzuki } \\
\text { and Kawamura 1994; } \\
\text { Kayastha 1997; } \\
\text { Booth and Cullen } \\
\text { 2001; Bordeau et al. } \\
2002\end{array}$ & $\begin{array}{l}\text { Ewert and Jamieson } \\
2003\end{array}$ \\
\hline Biking & & $\begin{array}{l}\text { Goeft and Alder } \\
2000\end{array}$ & $\begin{array}{l}\text { Ewert and Jamieson } \\
2003\end{array}$ \\
\hline Wildlife, terrestrial & Shackley 1996b & & $\begin{array}{l}\text { Sournia 1996; Sekhar } \\
\text { 2003; Lamprey and } \\
\text { Reid } 2004\end{array}$ \\
\hline $\begin{array}{l}\text { Wildlife, marine and } \\
\text { estuarine }\end{array}$ & $\begin{array}{l}\text { Davis et al. 1997; } \\
\text { Ryan 1998; Ryan and } \\
\text { Harvey 2000; Wilson } \\
\text { and Tisdell 2001; } \\
\text { Scott and Laws 2004 }\end{array}$ & $\begin{array}{l}\text { Duffus and Dearden } \\
\text { 1993; Duffus 1996; } \\
\text { Berrow 2003; } \\
\text { Parsons et al 2003; }\end{array}$ & \\
\hline
\end{tabular}




\section{References}

ADAMS, W. M. and M. INFIELD 2003, Who is on the gorilla's payroll? Claims on tourist revenue from Ugandan National Park. World Development 31: 177190.

ADELMAN, B. J., T.A. HEBERLEIN, and T.M. BONNICKSEN 1982. Social psychological explanations for the persistence of a conflict between paddling canoeists and motor craft users in the Boundary Waters Canoe Area. Leisure Sciences 5: 45-62.

ALLISON, W. R. 1996. Snorkeler damage to reef corals in the Maldive Island. Coral Reefs 15: 215-218.

ARCHABALD, K. and L. NAUGHTON-TREVES 2001. Tourism revenue sharing around national parks in Western Uganda: early efforts to identify and reward local communities. Environmental Conservation 28: 135-149.

ARNOULD, E. and I. PRICE 1993. River magic: extraordinary experience and the extended service encounter. Journal of Consumer Research 20: 24-45.

BARNES, J. I., C. SCHIER and G. VAN ROOY 1999. Tourists' willingness to pay for wildlife viewing and wildlife conservation in Namibia. South African Journal of Wildlife Research 29: 101-111.

BEALE, C.M. and P. MONAGHAN 2004. Human disturbance: people as predationfree predators? Journal of Applied Ecology 41: 335-343.

BEEDIE, P. 2003. Mountain guiding and adventure tourism: reflections on the choreography of the experience. Leisure Sciences 22: 147-167.

BEJDER, L., S.M. DAWSON and J.A. HARRAWAY 1999. Responses by Hector's dolphins to boats and swimmers in Porpoise Bay, New Zealand. Marine Mammal Science 15: 738-750.

BENTLEY, T., S.J. PAGE and I.S. LAIRD 2000. Safety in New Zealand's adventure tourism industry: the client accident experience of adventure tourism operators. Journal of Travel Medicine 7: 239-245.

BENTLEY, T.A. and S.J. PAGE 2001. Scoping the extent of adventure tourism accidents. Annals of Tourism Research 28: 705-726.

BENTLEY, T., S.J. PAGE and I. LAIRD. 2001a. Accidents in the New Zealand adventure tourism industry. Safety Science 38: 31-48.

BENTLEY, T.A., D. MEYER, S.J. PAGE and D. CHALMERS 2001b. Recreational tourism injuries among visitors to New Zealand: An exploratory analysis using hospital discharge data. Tourism Management 22: 373-381.

BENTLEY, T., S.J. PAGE, D. MEYER, D. CHALMERS and I. LAIRD 2001c. How safe is adventure tourism in New Zealand: an exploratory analysis. Applied Ergonomics 32: 327-338.

BENTLEY, T., S.J. PAGE and I. LAIRD 2003. Managing tourist safety: the experience of the adventure tourism industry. In Wilks, J. and S.J. Page, (eds) Managing Tourist Health and Safety in the New Millennium. Pergamon, Elsevier Science, Oxford, UK: 85-100.

BERROW, S. D. 2003. Developing sustainable whalewatching in the Shannon estuary. In Garrod, B. and C. Wilson, (eds) Marine ecotourism: Issues and Experiences. Channel View, Clevedon, UK: 198-203.

BLAHNA, D.J., K.S. SMITH and J.A ANDERSON 1995. Backcountry llama packing: visitor perceptions of acceptability and conflict. Leisure Sciences 17: 
185-204.

BLANE, J.M. and R. JAAKSON 1994. The impact of ecotourism boats on the St Lawrence beluga whales. Environmental Conservation 21: 267-269.

BOOTH, K. L. and R. CULLEN 2001. Managing recreation and tourism in New Zealand mountains. Mountain Research and Development 21: 331-334.

BOURDEAU, P., J. CORNELOUP and P. MAO 2002. Adventure sports and tourism in the French Mountains: dynamics of change and challenges for sustainable development. Current Issues in Tourism 5: 22-32.

BOWKER, J.M 2001. Outdoor Recreation by Alaskans: Projections for 2000 Through 2020. USDA Forest Service, Pacific Northwest Research Station, Portland, USA.

BOWKER, J.M., D.B.K. ENGLISH and J.A. DONOVAN 1996. Toward a value for guided rafting on southern rivers. Journal of Agricultural and Applied Economics 28: 423-432.

BREIVIK, G. 1996. Personality, sensation seeking and risk taking among Everest climbers. International Journal of Sport Psychology 27: 308-320.

BUCKLEY, R.C. 1998. Ecotourism megatrends. Australian International Business Review 1998: 52-54.

BUCKLEY R.C. 2000. NEAT trends: current issues in nature, eco and adventure tourism. International Journal of Tourism Research 2: 437-444

BUCKLEY, R.C. 2004a. Skilled commercial adventure: the edge of tourism. In: Singh, T.V. ed. New Horizons in Tourism. CAB International, Oxford: 37-48.

BUCKLEY, R.C. 2004b. Impacts of ecotourism on birds. In Buckley, R. (ed) Environmental Impacts of Ecotourism. CAB International, Oxford: 187-209.

BUCKLEY, R.C. 2004c. Impacts of ecotourism on terrestrial wildlife. In Buckley, R. (ed) Environmental Impacts of Ecotourism. CAB International, Oxford: 211228.

BUCKLEY, R.C. 2006. Adventure Tourism. CAB International, Oxford.

BYRD, J.H. and W.F. HAMILTON 1997. Underwater cave diving fatalities in Florida: a review and analysis. Journal of Forensic Sciences 42: 807-811.

CAMP, R.J. and R.I. KNIGHT 1998. Rock climbing and cliff bird communities at Joshua Tree National Park, California. Wildlife Society Bulletin 26: 892-898.

CARLSON, C. 2001. A Review of WhaleWatching Guidelines and Regulations Around the World. International Fund for Animal Welfare, Yarmouth Port, USA.

CAROTHERS, P., J.J. VASKE and M.P. DONNELLY 2001. Social values versus interpersonal conflict between hikers and mountain bikers. Leisure Sciences 23: 47-61.

CATER, C. I. 2005. Playing with risk? Participant perceptions of risk and management complications in adventure tourism. Tourism Management 27(2): 317-325.

CHERON, E. and B. RITCHIE 1982. Leisure activities and perceived risk. Journal of Leisure Research. 14: 139-154.

CHHETRI, P., C. ARROWSMITH and M. JACKSON 2004. Determining hiking experiences in nature-based tourist destinations. Tourism Management 25: 3143.

COLE, D. N. 1996. Wilderness recreation in the United States - trends in use, users, and impacts. International Journal of Wilderness 2: 14-18. 
COLE, D.N 2004. Impacts of hiking and camping on soils and vegetation: a review. In Buckley, R.C (ed) Environmental Impacts of Ecotourism. CAB International, Oxford, UK: 41-60.

CONSTANTINE, R. 2000. Increased avoidance of swimmers by wild bottlenose dolphins Tursiop truncatus due to longterm exposure to swim-with-dolphin tourism. Marine Mammal Science 17: 689-702.

CORDELL, H.K. and J.C. TROM 1991. methodology for assessing national outdoor recreation and supply trends. Leisure Sciences 13:1-20.

CORKERON, P. J. 1995.Humpback whales Megaptera novaeangliae in Hervey Bay, Queensland: behavior and responses to whale-watching vessels. Canadian Journal of Zoology 73:1290-1299.

CRAWFORD, D.W., E.L. JACKSON and G. GODBEY 1991. Leisure activities and perceived risk. Journal of Leisure Research 14: 139-154.

DAVIS, D.C. and C.A. TISDELL 1996. Economic management of recreational scuba diving and the environment. Journal of Environmental Management 48: 229248.

DAVIS, D.C., S. BANKS, A. BIRTLES, P. VALENTINE and M. CUTHILL 1997. Whale sharks in Ningaloo Marine Park: managing tourism in an Australian marine protected area. Tourism Management 18: 259-271.

DAVIS, D.C. and C.A. TISDELL 1998. Tourist levies and willingness to pay for a whale shark experience. Tourism Economics 5: 161-174.

DEIBERT, M., D. ARONSSON, R.J. JOHNSON, C. ETTLINGER and J. SHEALY 1998. Skiing injuries in children, adolescents and adults. Journal of Bone and Joint Surgery \{American Volume] 80: 25-32.

DELLE FAVE, A., M. BASSI and F. MASSIMINI 2003. Quality of experience and risk perception in high-altitude rock climbing. Journal of Applied Sport Psychology 15: 82-98.

DEVALL, B. and J. HARRY 1981. Who hates whom in the great outdoors: The impact of recreation specialization and technologies of play. Leisure Sciences 4: 399-418.

DUFFUS, D. A. and P. DEARDEN 1993. Recreational use, valuation, and management of killer whales Orcinus orca on Canada's Pacific Coast. Environmental Conservation 20: 149-156.

DUFFUS, D. 1996. The recreational use of grey whales in southern Clayoquot Sound, Canada. Applied Geography 16: 179-190.

EASSON, S. 2006. Philosophies of Adventure and Extreme Sports. Meaning, Motivation and Sporting Danger. Routledge, New Zealand, in press.

ENGLISH, D.B.K. and J.M. BOWKER 1996. Economic impacts of guided whitewater rafting: a study of five rivers. Water Sources Bulletin 32: 13191328.

EWERT, A.W. 1994. Playing the edge: motivation and risk taking in a high-altitude wildernesslike environment. Environment and Behaviour 26: 3-24.

EWERT, A.W. and S. HOLLENHORST 1989. Testing the adventure model: empirical support for a model of risk recreation participation. Journal of Leisure Research 21: 124-139.

EWERT, A.W. and L. JAMIESON 2003. Current status and future directions in the adventure tourism industry. In Wilks, J. and S.J. Page, (eds) Managing Tourist Health and Safety in the New Millennium. Pergamon, Oxford, UK: 6783.

FARMER, R. J. 1992. Surfing: motivations, values and culture. Journal of Sport 
Behavior 15: 241-257.

FARRIS, M. A. 1998. The effects of rock climbing on the vegetation of three Minnesota cliff systems. Canadian Journal of Botany 76: 1-10.

FEDERIUK, C.S., J.L. SCHLUETER and A.L. ADAMS 2002. Skiing, snowboarding, and sledding injuries in a northwestern state. Wilderness and Environmental Medicine 13: 245-249.

FEHER, P., M.C MEYERS and W.A. SKELLY 1998. Psychological profile of rock climbers: state and trait attributes. Journal of Sport Behavior 21: 167-180.

FENNELL, D. 1999. Ecotourism: An Introduction. Routledge, London, UK.

FIX, P. and J.B. LOOMIS 1997. The economic benefits of mountain biking at one of its Meccas: an application of the travel cost method to mountain biking in Moab, Utah. Journal of Leisure Research 39: 342-352.

FLUKER, M. R. and L.W. TURNER 2000. Needs, motivations, and expectations of a commercial whitewater rafting experience. Journal of Travel Research 38: 380-389.

GARRICK, J. G. and L.T. KURLAND 1971. The epidemiological significance of unreported ski injuries. Journal of Safety Research 3: 182-187.

GARROD, B. and D.A. FENNELL 2004. An analysis of whalewatching codes of conduct. Annals of Tourism Research 31: 334-352.

GJERDALEN, G. and P. WILLIAMS 2000. An evaluation of the utility of a whale watching code of conduct. Tourism Recreation Research 25: 27-37.

GOEFT, U. and J. ALDER 2000. Mountain bike rider preferences and perceptions in the south-west of Western Australia. CALM Science 3: 261-275.

GOULET, C., G. REGNIER, G. GRIMARD, P. VALOIS and P. VILLENEUEVE 1999. Risk factors associated with alpine skiing injuries in children: a casecontrol study. American Journal of Sports Medicine 27: 644-650.

GREEN, E., and R. DONNELLY 2003. Recreational scuba diving in Caribbean marine protected areas: do the users pay? Ambio 32: 140-144.

GRIJALVA, T. C., R.P. BERRENS, A.K. BOHARA, P.M. JAKUS and W. SHAW 2002. Valuing the loss of rock climbing access in wilderness areas: a nationallevel, random-utility model. Land Economics 78: 103-120.

GYIMOTHY, S. and R.J. MYKLETUN 2004. Play in adventure tourism: the case of Arctic trekking. Annals of Tourism Research 51: 855-878.

HADLEY, G. L., and K.R. WILSON 2004. Patterns of small mammal density and survival following ski-run development. Journal of Mammalogy 85: 97-104.

HAGEL, B. E., C. GOULET, R.W. PLATT and B. PLESS 2004. Injuries among skiers and snowboarders in Quebec. Epidemiology 15: 279-286.

HAMMITT, W. and C. COLE 1998. Wildland Recreation: Ecology and Management, $2^{\text {nd }}$ ed. John Wiley, New York.

HANLEY, N., G. KOOP, B. ALVAREZ-FARIZO, R.E. WRIGHT and C. NEVIN 2001. Go climb a mountain: an application of recreation demand modelling to rock climbing in Scotland. Journal of Agricultural Economics 51: 36-52.

HANLEY, N., W.S. SHAW and R.E. WRIGHT 2003. The New Economics of Outdoor Recreation. Edward Elgar Publishing Ltd, Cheltenham, UK.

HAWKINS, J. P. and C.M. ROBERTS 1994. The growth of coastal tourism in the Red Sea: present and future effects on coral reefs. Ambio 23: 503-507.

HAWKINS, J. P., C.M. ROBERTS, T. VAN'T HOF, K. DE MEYER, J. TRATALOS and C. ALDAM 1999. Effects of recreational scuba diving on Caribbean coral and fish communities. Conservation Biology 13: 888-897. 
HENDEE, J.C. and C.P DAWSON 2002. Wilderness Management, $3^{\text {rd }}$ edn. WILD Foundation and Fulcrum Publishing, Colorado.

HENDRICKS, W.W. 1995. A resurgence in recreation conflict research: introduction to the special issue. Leisure Sciences 17: 157-158.

HOLYFIELD, L. 1999. Manufacturing adventure: the buying and selling of emotions. Journal of Contemporary Ethnography 28: 3-32.

HOYT, E. 2000. Whale-Watching 2000: Worldwide Tourism Numbers, Expenditures, and Expanding Socioeconomic Benefits. International Fund for Animal Welfare, Crowborough, UK.

HUDSON, S. 2002. Sport and Adventure Tourism. Haworth Hospitality Press, New York.

INGLIS, G.J., V.I. JOHNSON and F. BLACK 1999. Crowding norms in marine settings: A case study on snorkelling on the Great Barrier Reef. Environmental Management 24: 369-381.

JACK, S. J. and K.R. RONAN 1998. Sensation seeking among high and low risk sports participants. Personality and Individual Differences 25: 1063-1083.

JACKSON, E. L. and R. WONG 1982. Perceived conflict between urban crosscountry skiers and snowmobilers in Alberta. Journal of Leisure Research 14: 47-62.

JACOB, G. R. and R. SCHREYER 1980. Conflict in outdoor recreation: a theoretical perspective. Journal of Leisure Research 12:368-380.

JAKUS, P. and W.D. SHAW 1997. Congestion at recreation areas: empirical evidence on perceptions, mitigating behaviour and management preferences. Journal of Environmental Management 50: 398-401.

JAMESON, S. C., M.S.A. AMMAR, E. SAADALLA, H.M. MOSTAFA and B. RIEGL 1999. A coral damage index and its application to diving sites in the Egyptian Red Sea. Coral Reefs 18: 333-339.

JOHNSON, B. and T. EDWARDS 1994. The commodification on mountaineering. Annals of Tourism Research 21: 459-478.

JOHNSON, R.J., C.F. ETTLINGER, J.F. SHEALY and C. MEADER 1997. Impact of super sidecut skis on the epidemiology study of skiing injuries. Sportverletz Sportschaden 11: 150-152.

KAYASTHA, S. L. 1997. Tourism and environment in the Himalayan region. In Nag, P., V.K. Kumra and Singh, J. (eds) Geography and Environment: Volume Two, Regional Issues. Concept Publishing Company, India.

KNOPP, D. and J. TYGER 1973. A study of conflict in recreational land use: snowmobiling vs. ski-touring. Journal of Leisure Research 5: 6-17.

KOVACS, K. M., and S. INNES. 1990. The impact of tourism on harp seals Phoca groenlandica in the Gulf of St. Lawrence, Canada. Applied Animal Behaviour Science 26: 15-26.

LAMPREY, R. H. and R.S. REID 2004. Expansion of human settlement in Kenya's Maasai Mara: what future for pastoralism and wildlife? Journal of Biogeography 21: 997-1032.

LEVY, A. S., A.P. HAWKES, L.M. HEMMINGER and S. KNIGHTS 2002. An analysis of head injuries among skiers and snowboarders. Journal of Trauma 53: 695-704.

LIVET, R. 1997. From sports diving to underwater tourism. Cahiers Espaces 1997: 62-68.

MACHOLD, W., O. KWASNY and P. GABLER 2000. Risk of injury through snowboarding. Journal of Trauma 48: 1109-1114. 
MACHOLD, W., O. KWANSY, P. EISENHARDT, A. KOLONJA, E. BAUER, S. LEHR, W. MAYR and M. FUCHS 2002. Reduction of severe wrist injuries in snowboarding by an optimized wrist protection device: a prospective randomized trial. Journal of Trauma 52: 517-520.

MACNAB, A.J., T. SMITH, F.A. GAGNON and M. MACNAB 2002. Effect of helmet wear on the incidence of head/face and cervical spine injuries in young skiers and snowboarders. Injury Prevention 8: 324-327.

MALCOLM, M. 2001. Mountaineering fatalities in Mt Cook National Park. New Zealand Journal of Medicine 114: 78-80.

MALLETT, J. 1998. Plenary address. Seventh World Congress of Adventure Travel and Ecotourism. Quito, Ecuador.

MANNING, R.E. 1999. Studies in Outdoor Recreation. $2^{\text {nd }}$ Edn. Oregon UP, Corvallis.

MANNING, R.E. and. W.A. FREIMUND 2004. Use of visual research methods to measure standards of quality for parks and outdoor recreation. Journal of Leisure Research 36: 557-579.

MANNING, R.E., S. LAWSON, P. NEWMAN, M. BUDRUK, W. VALLIERE, D. LAVEN and J. BACON 2004. Visitor perceptions of recreation-related resource impacts. In Buckley, R. (ed) Environmental Impacts of Ecotourism. CAB International, Oxford: 259-272.

MANNING, R.E., S. LAWSON, P. NEWMAN, D. LAVEN and W. VALLIERE 2002. Methodological issues in measuring crowding-related norms in outdoor recreation. Leisure Sciences 24: 339-348.

MARION, J.L and Y. LEUNG 2004. Environmentally sustainable trail management. In Buckley, R. (ed) Environmental Impacts of Ecotourism. CAB International, Oxford: 229-244.

MATSUMOTO, K., K. MIYAMOTO, H. SUMI, Y. SUMI and K. SHIMIZU 2002. Upper extremity injuries in snowboarding and skiing: a comparative study. Clinical Journal of Sport Medicine 12: 354-359.

MEDIO, D., R.F.G. ORMOND and M. PEARSON 1997. Effect of briefings on rates of damage to corals by scuba divers. Biological Conservation 79: 91-95.

MUNDET, L. and L. RIBERA 2001. Characteristics of divers at a Spanish resort. Tourism Management 22: 501-510.

MUSA, G. 2003. Sipadan: an over-exploited scuba-diving paradise? An analysis of tourism impact, diver satisfaction and management priorities. In Garrod, B. and J.C Wilson (eds) Marine Ecotourism: Issues and Experiences. Channel View, Clevedon, UK: 122-137.

MVULA, C. D. 2001. Fair trade in tourism to protected areas - a micro case study of wildlife tourism to South Luangwa National Park, Zambia. International Journal of Tourism Research 3: 393-405.

NATHANSON, A., P. HAYNES and D. GALANIS 2002. Surfing injuries. American Journal of Emergency Medicine 20: 155-150.

NEEDHAM, M. D., R.B ROLLINS and C.J.B. WOOD 2004. Site-specific encounters, norms and crowding of summer visitors at Alpine ski areas. International Journal of Tourism Research 6: 421-437.

NEUMANN, P.W. and H.G. MERRIAM 1972. Ecological effects of snowmobiles. Canadian Field Naturalist 86: 207-212.

NEWSOME, D., S.A. MOORE and R.K. DOWLING 2001. Natural Area Tourism: Ecology, Impacts and Management. Channel View, Clevedon. 
NEWSOME, D., D.N. COLE and J.L MARION 2004. Environmental impacts associated with recreational horse-riding. In Buckley, R.C. (ed) Environmental Impacts of Ecotourism. CAB International, Oxford, UK: 6182.

NOWACEK, S. M., R.S. WELLS and A. SOLOW 2001. Short-term effects of boat traffic on bottlenose dolphins, Tursiops truncatus, in Sarasota Bay, Florida. Marine Mammal Science 17: 673-688.

NOWACEK, S.M., R.S. WELLS, E.C.G. OWEN, T.R. SPEAKMAN, R.O. FLAMM and D.P. NOWACEK 2004. Florida manatees, Trichechus manatus latirostris, respond to approaching vessels. Biological Conservation 119: 517-523.

OLLENBURG, c. (2005) Worldwide Structure of the Equestrian Tourism Sector. Journal of Ecotourism 4: 47-55.

O'NEILL, M., M. MACCARTHY and P.A. WILLIAMS 2002. Dive tourism: evaluating service quality. FIU Hospitality Review 20: 47-65.

OUTDOOR INDUSTRY ASSOCIATION (2005) Outdoor Recreation Participation in the United States, $7^{\text {th }}$ Edition

http://www.outdoorindustry.org/research.current.html Accessed on 1 December 2005.

PAGE, S.J. and R.K. DOWLING 2002. Ecotourism. Pearson Education, Harlow, UK.

PAGE, S.J., T. BENTLEY and D. MEYER 2003. Evaluating the nature, scope and extent of tourist accidents: the New Zealand experience. In Wilks, J. and S.J. Pages, (eds) Managing Tourist Health and Safety in the New Millennium. Elsevier Science, Oxford, UK: 35-52.

PAGE, S. J., T. BENTLEY and L. WALKER 2005. Scoping the nature and extent of adventure tourism operations in Scotland: how safe are they? Tourism Management 26: 381-397.

PARK, T., J.M. BOWKER and V.R. LEEWORTHY 2002. Valuing snorkeling visits to the Florida Keys with stated and revealed preference models. Journal of Environmental Management 65: 301-312.

PARKER, J.D. and B. AVANT 2000. In their own words: wilderness values of outfitter/guides. In McCool, S.F., D.N. Cole, W.T. Borrie and J. O’Laughlin (comps) Wilderness Science in a Time of Change- Volume 3: Wilderness as a Place for Scientific Inquiry. Proceedings RMRS-P-15-VOL-3. USDA Forest Service, Rocky Mountain Research Station, Ogden, UT.: 196-201.

PARSONS, E.C.M., C.A. WARBURTON, A. WOODS-BALLARD, A. HUGHES and P. JOHNSTON 2003. The value of conserving whales: the impacts of whale-watching on the economy of rural west Scotland. Aquatic Conservation 13: 397-415.

PRALL, J., K. WINSTON R. and R. BRENNAN 1995. Severe snowboarding injuries. Injury 26: 539-542.

RAMTHUN, R. 1995. Factors in user group conflict between hikers and mountain bikers. Leisure Sciences 17: 159-169.

REQUA, R.K., J.M. TONEY and J.G. GARRICK 1977. Parameters on injury reporting in skiing. Medical Science of Sports Exercise 9: 185-190.

RONNING, R., T. GERNER and L. ENGEBRETSEN 2000. Risk of injury during alpine and telemark skiing and snowboarding. American Journal of Sports Medicine 28: 506-508.

ROUPHAEL, A.B. and G.J. INGLIS 2001. Increased spatial and temporal variability in coral damage caused by recreation scuba diving. Ecological Applications 12: 427-440. 
RYAN, C. and K.HARVEY 2000. Who likes saltwater crocodiles? Analysing sociodemographics of those viewing tourist wildlife attractions based on saltwater crocodiles. Journal of Sustainable Tourism 8: 426-433.

RYAN, C. 2003. Risk acceptance in adventure tourism - paradox and content. In: Wilks, J. and S.J. Page (eds) Managing Tourist Health and Safety in the New Millennium. Pergamon, Oxford: 55-66.

SCARPACI, C., S.W. BIGGER, P.J CORKERON and D. NUGEGODA 2000. Bottlenose dolphins, Tursiops truncatus, increase whistling in the presence of "swim-with-dolphin" tour operators. Journal of Cetacean Research and Management 2: 183-186.

SCARPACI, C. and N. DAYANTHI 2003. Compliance with regulations by swimwith-dolphins: operations in Port Phillip Bay, Victoria, Australia. Environmental Management 31: 342-347.

SCHAEFFER, T.N., M.S. FOSTER, M.E. LANDRAU and R.K. WALDER 1999. Diver disturbance in kelp forests. California Fish and Game 85: 170-176.

SCHLEYER, M.H. and B.J. TOMALIN 2000. Damage on South African coral reefs and an assessment of their sustainable diving capacity using a fisheries approach. Bulletin of Marine Science 67: 1025-1042.

SCHNEIDER, I.E. 2000. Revisiting and revising recreation conflict research. Journal of Leisure Research 32: 129-132.

SCHOEN, R.G. and M.J. STANO 2002. Year 2000 whitewater injury survey. Wilderness and Environmental Medicine 13: 119-124.

SCHUSTER, R.M., J.G. THOMPSON and W.E. HAMMITT 2001. Rock climbers' attitudes toward management of climbing and the use of boolts. Environmental Management 28: 403-412.

SCOTT, N. and E. LAWS 2004. Whale watching - the roles of small firms in the evolution of a new Australian niche market. In Thomas, R. (ed) Small Firms in Tourism: International Perspectives. Elsevier Science, Amsterdam.

SEKHAR, N. U. 2003. Local people's attitudes towards conservation and wildlife tourism around Sariska Tiger Reserve, India. Journal of Environmental Management 69: 339-347.

SHACKLEY, M. 1996a. Community impact of the camel safari industry in Jaisalmar, Rajasthan. Tourism Management 17: 213-218.

SHACKLEY, M. 1996b. Wildlife Tourism. International Thomson Business Press, London.

SHACKLEY, M. 1998. 'Stingray City' - managing the impact of underwater tourism in the Cayman Islands. Journal of Sustainable Tourism 6: 328-338.

SHARPE, R. 2005. "Going above and beyond:" the emotional labor of adventure guides. Journal of Leisure Research 37: 29-50.

SHELBY, B. 1980. Contrasting recreational experiences: motors and oars in the Grand Canyon. Journal of Soil and Water Conservation 35: 129-131.

SHELBY, B. 1981. Encounter norms in backcountry settings: studies of three rivers. Journal of Leisure Research 13: 129-138.

SHELBY, B., J.J. VASKE and M.P. DONNELLY 1996. Norms, standards and natural resources. Leisure Sciences 18: 103-123.

SLANGER, E. and E. RUDESTAM 1997. Motivation and disinhibition in high risk sports: Sensation seeking and self efficacy. Journal of Research in Personality 31: 355-374.

SOURNIA, G. 1996. Wildlife tourism in West and Central Africa. Ecodecision 20: 52-54. 
SWARBROOKE, J., C. BEARD, S. LECKIE and G. POMFRET 2003. Adventure Tourism: the New Frontier. Butterworth-Heinemann, London.

TABATA, R.S. 1989. The use of nearshore dive sites by recreational dive operations in Hawaii. Coastal Zone 89: 2865-2875.

TABATA, R. S. 1992. Scuba diving holidays. In Tabata, R.S., B. Weiler and C.M. Hall (eds) Special Interest Tourism. Belhavan Press, London, UK: 171-184.

TARAZI, F., M.F.S. DVORAK and P.C. WING 1999. Spinal injuries in skiers and snowboarders. American Journal of Sports Medicine 27: 177-180.

TAYLOR, D.M., K.S. O'TOOLE and C.M. RYAN 2003. Experienced scuba divers in Australia and the United States suffer considerable injury and morbidity. Wilderness and Environmental Medicine 14: 83-88.

THAPA, B. and A.R. GRAEFE 2003. Level of skill and its relationship to recreation conflict and tolerance among adult skiers and snowboarders. World Leisure 45: $13-25$.

THOMPSON, M. and K. HOMEWOOD 2002. Entrepreneurs, elites, and exclusion in Maasailand: trends in wildlife conservation and pastoralist development. Human Ecology 30: 107-138.

THURSTON, E. and R.J. READER 2001. Impacts of experimentally applied mountain biking and hiking on vegetation and soil of a deciduous forest. Environmental Management 27: 397-409.

TRATALOS, J.A. and T.J. AUSTIN 2001. Impacts of recreational SCUBA diving on coral communities of the Caribbean island of Grand Cayman. Biological Conservation 102: 67-75.

TRAVEL INDUSTRY ASSOCIATION OF AMERICA 2005. Adventure Travel Report. http://www.tia.org Last viewed 25 November 2005.

TREVETT, A.J., R. FORBES, C.K. RAE, C. SHEEHAN, J. ROSS, S.J. WATT and R. STEPHENSON 2001. Diving accidents in sports divers in Orkney waters. Scottish Medical Journal 46: 176-177.

VAIL, D. and T. HELDT 2004. Governing snowmobilers in multiple-use landscapes: Swedish and Maine USA cases. Ecological Economics 48: 469-483.

VASKE, J., P. CAROTHERS, M.P. DONNELLY and B. BAIRD 2000. Recreation conflict among skiers and snowboarders. Leisure Sciences 22: 297-313.

VASKE, J. and M. DONNELLY 2002. Generalizing the encounter-norm-crowding relationship. Leisure Sciences 24: 255-270.

VASKE, J., R. DYAR and N. TIMMONS 2004. Skill level and recreation conflict among skiers and snowboarders. Leisure Studies 26: 215-225.

VASKE, J., A.R. GRAEFE, B. SHELBY and T. HEBERLEIN 1986. Backcountry encounter norms: Theory, method, and empirical evidence. Journal of Leisure Research 18: 137-153.

VITTERSO, J., R. CHIPENIUK, M. SKAR and O. VISTAD 2004. Recreational conflict is affective: the case of cross-country skiers and snowmobiles. Leisure Studies 26: 227-243.

WATSON, A.E., D.R. WILLIAMS and J.J. DAIGLE 1991. Sources of conflict between hikers and mountain bike riders in the Rattlesnake NRA. Journal of Park and Recreation Administration 9: 59-71.

WATSON, A.E., M.J. NICCOLUCCI and D.R. WILLIAMS 1994. The nature of conflict between hikers and recreational stock users in the John Muir Wilderness. Journal of Leisure Research 26: 372-385.

WATSON, A. E. 1995. An analysis of recent progress in recreation conflict research and perceptions of future challenges and opportunities. Leisure Sciences 17: 
235-238.

WATSON, A., D. COLE and J.W. ROGGENBUCK 1995. Trends in Wilderness Recreation Use Characteristics. In Thompson, J.L., D.W. Lime, B. Gartner and W.M. Sames, (eds) Proceedings of the Fourth International Outdoor Recreation and Tourism Trends Symposium and the 1995 National Resources Planning Conference. University of Minnesota, Minnesota, USA: 68-71

WATSON, A., and R. MOSS 2004. Impacts of ski-development on ptarmigan Lagopus mutus at Cairn Gorm, Scotland. Biological Conservation 116: 267275.

WEAVER, T. and D. DALE 1978. Trampling effects of hikers, motorcycles and horses in meadows and forests. Journal of Applied Ecology 15: 451-457.

WEAVER, D. 1998. Ecotourism in the Less Developed World, CAB International, Oxford, UK.

WELLMAN, J.D., J.W. ROGGENBUCK and A.C. SMITH 1982. Recreation specialization and norms of depreciative behaviour among canoeists. Journal of Leisure Research 14: 323-340.

WHINAM, J., E.J. CANNELL, J.B. KIRKPATRICK and M. COMFORT 1994. Studies on the potential impact of recreational horseriding on some alpine environments of the Central Plateau, Tasmania. Journal of Environmental Management 40: 103-117.

WILKIE, D.S. and J.F. CARPENTER 1999a. The potential role of safari hunting as a source of revenue for protected areas in the Congo Basin. Oryx 33: 339-345.

WILKIE, D.S. and J.F CARPENTER 1999b. Can nature tourism help finance protected areas in the Congo Basin? Oryx 33: 332-338.

WILKS, J. 1992. Introductory scuba diving on the Great Barrier Reef. Australian Parks and Recreation 28: 18-23.

WILKS, J. 1993. Scuba safety in Queensland. South Pacific Underwater Medicine Society Journal 23:139-141.

WILKS, J. 1999. Scuba diving safety on Australia's Great Barrier Reef. Travel Medicine International 17: 17-21.

WILKS, J. and R.J. DAVIS 2000. Risk management for scuba diving operators in Australia's Great Barrier Reef. Tourism Management 21: 591-599.

WILLIAMS, P., K. DOSSA and A. FULTON 1994. Tension on the slopes: managing conflict between skiers and snowboarders. Journal of Applied Recreation Research 19: 191-213.

WILLIAMSON, J.E. 1999. Accidents in North American Mountaineering. American Alpine Club, Boulder CO.

WILSON, C. and C.A. TISDELL 2001. Sea turtles as a non-consumptive tourism resource especially in Australia. Tourism Management 22: 279-288.

WYDER, T. 1987. 175 years of mountaineering in Switzerland. The Finsteraarhorn. Magglingen 44:2-4.

YAMAKAWA, H., S. MURASE, H. SAKAI, T. IWAMA, M. KATADA, S. NIIKAWA, Y. SUMI, Y. MISHIMURA and N. SAKAI 2001. Spinal injuries in snowboarders: risk of jumping as an integral part of snowboarding. Journal of Trauma 50: 1101-1105.

ZAKAI, D. and N.E. CHADWICK-FURMAN 2002. Impacts of intensive recreational diving on reef corals at Eilat, northern Red Sea. Biological Conservation 105: 179-187. 